\title{
Kajian Pemberian Asi Eksklusif, Berat badan lahir rendah, dan Status imunisasi dengan kejadian stunting
}

\author{
Sitti Zakiyyah Putri ${ }^{1}$, Dahniar ${ }^{2}$, Sumantri ${ }^{3}$ \\ .Dosen Universitas Muhammadiyah Makassar ${ }^{1,2}$;Pegawai RSUD Polewali Mandar ${ }^{3}$. \\ Email : ${ }^{1}$ zakiyyahputri1807@gmail.com
}

\begin{abstract}
Stunting is a physical growth in height that is not normal according to age. Stunting is influenced by multifactors including exclusive breastfeeding, low birth weight, and immunization status. The purpose of this study was to determine the relationship between exclusive breastfeeding, low birth weight, and immunization status with the incidence of stunting in toddlers. The research design used is observational analytic with a cross sectional study approach. The population in this study were all toddlers aged 25-60 months in the working area of the Banggae I Health Center, totaling 96 toddlers. The sampling technique used is, the first using cluster random sampling for the selection of health centers then the second using consecutive sampling with a total sample of 77 children under five. Data were collected using a questionnaire. Data analysis used person chi-square analysis and fisher's exact test with $=0.05$. Toddlers aged 25-60 months mostly receive exclusive breastfeeding, are born with normal weight, and have complete immunization status. Conclusion: the results of the analysis showed that there was no relationship between exclusive breastfeeding, low birth weight, and immunization status with the incidence of stunting in toddlers aged 25-60 months. Suggestion: improve health services for Puskesmas through early detection activities by measuring the height of children under five on a regular basis every month.
\end{abstract}

Keywords: stunting; exclusive breastfeeding; low birth weigh; immunization status

\begin{abstract}
ABSTRAK
Stunting merupakan pertumbuhan fisik tinggi badan yang tidak normal sesuai dengan umur. Stunting dipengaruhi oleh multifactor diantaranya adalah pemberian ASI eksklusif, berat badan lahir rendah, dan status imunisasi. Tujuan dari penelitian ini adalah untuk mengetahui hubungan pemberian ASI eksklusif, berat badan lahir rendah, dan status imunisasi dengan kejadian stunting pada balita. Desain penelitian yang digunakan yaitu analitik observational dengan pendekatan cross sectional study. Populasi dalam penelitian ini yaitu seluruh balita usia 2560 bulan yang ada diwilayah kerja Puskesmas Banggae I yang berjumlah 96 balita. Teknik pengambilan sampel yang digunakan yaitu, yang pertama menggunakan cluster random sampling untuk pemilihan puskesmas kemudian yang kedua menggunakan consecutive sampling dengan jumlah sampel sebanyak 77 balita. Data dikumpulkan dengan menggunakan kuesioner. Analisis data mengunakan analisis person chi-square dan fisher's exact test dengan $\alpha=0.05$. Balita usia 25-60 bulan sebagian besar mendapatkan ASI eksklusif, lahir dengan berat badan normal, dan mempunyai status imunisasi yang lengkap. Kesimpulan: hasil analisis menunjukkan bahwa tidak ada hubungan antara pemberian ASI eksklusif, berat badan lahir rendah, dan status imunisasi dengan kejadian stunting pada balita usia 25-60 bulan. Saran: meninngkatkan pelayanan kesehatan bagi Puskesmas melalui kegiatan deteksi dini dengan mengukur tinggi badan anak balita secara rutin tiap bulan.
\end{abstract}

Kata Kunci : stunting; pemberian ASI eksklusif; berat badan lahir rendah; status imunisasi 


\section{Vol. 16 No.2 Mei - Agustus 2021}

\section{PENDAHULUAN}

Stunting adalah bentuk dari proses pertumbuhan anak yang terhambat. Sampai saat ini stunting masih menjadi salah satu masalah gizi yang perlu mendapat perhatian. Stunting merupakan salah satu permasalahan gizi yang terjadi di Indonesia. Stunting adalah status gizi yang didasarkan pada indekx Tinggi Badan menurut Umur (TB/U) dengan ambang batas (Z-score) $<-2$ Standar Deviasi (SD) ${ }^{(1)}$. Dampak stunting tidak hanya dirasakan oleh individu yang mengalaminya, tetapi juga berdampak terhadap roda perekonomian dan pembangunan bangsa. Hal ini karena sumber daya manusia stunting memiliki kualitas lebih rendah dibandingkan dengan sumber daya manusia normal ${ }^{(2)}$ Kejadian stunting pada balita merupakan salah satu permasalahn gizi secara global, Saat ini banyak balita yang mengalami stunting dengan prevalensi yang cukup tinggi.

Masalah kesehatan masyarakat dianggap berat bila prevalensi stunting sebesar 30-39\% dan serius bila prevalensi stunting $\geq 40 \%$ (WHO, 2010). Sebanyak 13 provinsi termasuk kategori berat, dan sebanyak 15 provinsi termasuk kategori serius. Ke 15 provinsi tersebut adalah: Papua (40,1\%), Maluku (40,6\%), Sulawesi Selatan (40,9\%), Sulawesi Tengah (41,0\%), Maluku Utara $(41,1 \%)$, Kalimantan Tengah $(41,3 \%)$, Aceh $(41,5 \%)$, Sumatera Utara (42,5\%), Sulawesi Tenggara (42,6\%), Lampung $(42,6 \%)$, Kalimantan Selatan (44,2\%), Papua Barat $(44,7 \%)$, Nusa Tenggara Barat $(45,2 \%)$, Sulawesi Barat $(48,0 \%)$, dan Nusa Tenggara Timur $(51,7 \%){ }^{(1)}$. Angka kejadian stunting di Sulawesi barat cukup banyak yaitu sebesar
$48,0 \%$, dan menurut data dari Riskesdas tahun 2013 di kabupaten majene kejadian stunting sebanyak $58,62 \%$.

Gizi buruk kronik yang dialami semasa balita memiliki dampak yang buruk bagi tumbuh kembangnya. Studi menunjukkan bahwa anak pendek sangat berhubungan dengan prestasi pendidikan yang buruk, lama pendidikan yang menurun dan pendapatan yang rendah sebagai orang dewasa. Anak-anak pendek menghadapi kemungkinan yang lebih besar untuk tumbuh menjadi orang dewasa yang kurang berpendidikan, miskin, kurang sehat dan lebih rentan terhadap penyakit tidak menular. Oleh karena itu, anak pendek merupakan prediktor buruknya kualitas sumber daya manusia yang diterima secara luas, yang selanjutnya menurunkan kemampuan produktif suatu bangsa di masa yang akan datang (3). Penelitian yang dilakukan oleh Picauly \& Toy $(2013)^{(5)}$, mengenai pengaruh stunting terhadap prestasi belajar anak sekolah di Kupang dan Sumba Timur, NTT menunjukkan bahwa Siswa yang stunting lebih banyak memiliki prestasi belajar yang kurang, sementara siswa yang non stunting lebih banyak memiliki prestasi belajar yang baik. Intervensi untuk menurunkan anak pendek harus dimulai secara tepat sebelum kelahiran, dengan pelayanan pranatal dan gizi ibu, dan berlanjut hingga usia dua tahun. Proses untuk menjadi seorang anak bertubuh pendek yang disebut kegagalan pertumbuhan (growth faltering) - dimulai dalam rahim, hingga usia dua tahun. Pada saat anak melewati usia dua tahun, sudah terlambat untuk memperbaiki kerusakan pada tahun-tahun awal. Oleh karena itu, status 
kesehatan dan gizi ibu merupakan penentu penting tubuh pendek pada anak-anak ${ }^{(3)}$.

Fokus Gerakan perbaikan gizi adalah kepada kelompok 1000 hari pertama kehidupan, pada tataran global disebut dengan Scaling $U p$ Nutrition (SUN) dan di Indonesia disebut dengan Gerakan Nasional Sadar Gizi dalam Rangka Percepatan Perbaikan Gizi Pada 1000 Hari Pertama Kehidupan (Gerakan 1000 Hari Pertama Kehidupan dan disingkat Gerakan 1000 HPK). Gerakan SUN merupakan upaya baru untuk menghilangkan kekurangan gizi dalam segala bentuknya. Intervensi yang dilakukan pada SUN adalah intervensi spesifik dan intervensi sensitive. Intervensi spesifik adalah tindakan atau kegiatan yang dalam perencanaannya ditujukan khusus untuk kelompok 1000 hari pertama kehidupan (HPK) dan bersifat jangka pendek. Kegiatan ini pada umumnya dilakukan pada sector kesehatan, seperti imunisasi, PMT ibu hamil dan balita, monitoring pertumbuhan balita di Posyandu, suplemen tablet besi-folat ibu hamil, promosi ASI Eksklusif, MP-ASI, dan sebagainya. Sedangkan intervensi sensitif adalah berbagai kegiatan pembangunan di luar sector kesehatan yang ditujukan pada masyarakat umum. Beberapa kegiatan tersebut adalah penyediaan air bersih, sarana sanitasi, berbagai penanggulangan kemiskinan, ketahanan pangan dan gizi, fortifikasi pangan, pendidikan dan KIE Gizi, pendidikan dan KIE Kesehatan, kesetaraan gender, dan lain-lain ${ }^{(4)}$.

Beberapa penelitian mengenai faktorfaktor penyebab stunting antara lain : Penelitian yang dilakukan oleh Picauly \& Toy $(2013)^{(5)}$, tentang pengaruh stunting terhadap prestasi belajar anak sekolah di Kupang dan Sumba
Timur, NTT menunjukkan bahwa faktor-faktor determinan stunting adalah faktor pendapatan keluarga, pengetahuan gizi ibu, pola asuh ibu, riwayat infeksi penyakit, riwayat imunisasi, asupan protein dan pendidikan ibu. Sedangkan penelitian yang dilakukan oleh Bentian, Mayulu \& Rattu (2015) ${ }^{(6)}$, mengenai Faktor Resiko Terjadinya Stunting Pada Anak TK Di Wilayah Kerja Puskesmas Siloam Tamako Kabupaten Kepulauan Sangihe Propinsi Sulawesi Utara menunjukkan bahwa BBLR dan pemberian ASI Eksklusif merupakan faktor resiko terjadinya stunting dan imunisasi bukan termasuk faktor resiko terjadinya stunting. Hasil penelitian lain yang dilakukan oleh Oktariana (2012) (2), kejadian stunting dipengaruhi oleh berat badan lahir, asupan energy dan protein, status imunisasi, usia balita, jenis kelamin, status penyakit infeksi, pendidikan orang tua dan status ekonomi.

Data kejadian stunting di Puskesmas Banggae I belum diketahui secara pasti angka kejadiannya. Berdasarkan hasil wawancara dengan petugas puskesmas, selama ini belum dilakukan pencatatan secara detail sehngga data kejadian stunting tidak tercatat jelas. Deteksi dini tumbuh kembang tidak terlaksana dengan maksimal, petugas tidak melakukan pengukuran tinggi badan tiap bulannya, petugas hanya melakukan pengukuran tinggi badan minimal 2x/tahun. Hal inilah yang menjadi kendala petugas puskesmas tidak memiliki data secara jelas dan pasti. Berdasarkan data yang didapatkan dari puskesmas, terdapat 963 balita yaitu laki-laki sebanyak $518 \quad(53,8 \%)$ dan perempuan sebanyak 445 (46,2\%). Ada beberapa data balita yang mengalami gizi kurang dan 
Vol. 16 No.2 Mei - Agustus 2021

BGM namun tidak semuanya mempunyai data TB. Balita yang memiliki data TB hanya 16 , dari 16 balita yang memiliki data TB terdapat 14 balita yang mengalami stunting. Dan berdasarkan hasil Riset Kesehatan Dasar tahun 2013 menyimpulkan bahwa Sulawesi Barat masuk dalam 3 besar dengan kejadian stunting tertinggi sebesar (48\%) sedangkan kejadian stunting tahun 2016 dengan kategori pendek sebesar $23 \%$ dan kategori sangat pendek sebesar $14,7 \%{ }^{(1)}$.

Berdasarkan hasil uraian diatas maka peneliti tertarik untuk meneliti tentang "Hubungan Pemberian Asi Eksklusif, Berat Badan Lahir dan Status Imunisasi dengan kejadian stunting pada balita”.

\section{Tujuan}

\section{Hasil}

1. Distribusi Responden Berdasarkan Umur Ibu

\begin{abstract}
Mengetahui Hubungan Pemberian Asi Eksklusif, Berat Bayi Lahir Rendah dan Status Imunisasi dengan kejadian stunting.
\end{abstract}

\section{Hipotesis}

Ada hubungan antara pemberian ASI eksklusif, Berat badan lahir rendah, status imunisasi dengan kejadian stunting

\section{Metode Penelitian}

Desain penelitian yang digunakan dalam penelitian ini adalah analitik observasional dengan pendekatan cross sectional. Desain ini dipilih karena kegunaan dari desain cross sectional, yaitu untuk mempelajari dinamika korelasi antara faktor-faktor risiko dengan efek dengan cara pendekatan, observasi, atau pengumpulan data sekaligus yang artinya tiap subjek penelitian hanya diobservasi sekali saja ${ }^{(7)}$.

Tabel 1

Distribusi Responden Berdasarkan Umur Ibu Di Wilayah Kerja Puskesmas Banggae I Kab. Majene

\begin{tabular}{cccc}
\hline NO & Umur Responden (Ibu) & (n) & $(\boldsymbol{\%})$ \\
\hline 1 & $20-29$ tahun & 34 & 44.2 \\
2 & $30-39$ tahun & 36 & 46.8 \\
3 & $40-50$ tahun & 7 & 9.1 \\
\hline & Total & $\mathbf{7 7}$ & $\mathbf{1 0 0 . 0}$ \\
\hline
\end{tabular}

Tabel di atas menunjukkan bahwa responden dengan persentase kelompok umur tertinggi yaitu umur 30-39 tahun yakni sebanyak 36 orang (46.8\%) dan persentase pada kelompok umur terendah yaitu 4045 tahun yakni sebanyak 7 orang $(9.1 \%)$.

2 Distribusi Responden Berdasarkan Pekerjaan Ibu

Tabel .2

Distribusi Responden Berdasarkan Pekerjaan Ibu Di Wilayah Kerja Puskesmas Banggae I Kab. Majene 


\begin{tabular}{cccc}
\hline NO & Pekerjaan Responden (Ibu) & (n) & (\%) \\
\hline 1 & Tidak Bekerja/URT & 55 & 71.4 \\
2 & PNS/TNI/POLRI & 7 & 9.1 \\
3 & Dagang/Wiraswasta & 4 & 5.2 \\
4 & Sukarela/Honorer & 11 & 14.3 \\
\hline & Total & $\mathbf{7 7}$ & $\mathbf{1 0 0 . 0}$ \\
\hline
\end{tabular}

Berdasarkan tabel di atas menunjukkan bahwa dominan pekerjaan responden dari 77 responden adalah Tidak Bekerja/URT yakni sebanyak 55 orang (71.4\%) dan distribusi pekerjaan responden yang terendah adalah Dagang/Wiraswasta yakni sebanyak 4 orang (5.2\%). Responden dengan pekerjaan PNS/TNI/POLRI sebanyak 7 orang (9.1\%) dan Sukarela/Honorer sebanyak 11 orang (14.3\%).

3 Distribusi Responden Berdasarkan Pendidikan Ibu

Tabel .3

Distribusi Responden Berdasarkan Pendidikan Ibu Di Wilayah Kerja Puskesmas Banggae I Kab. Majene

\begin{tabular}{cccc}
\hline NO & Pendidikan Responden (Ibu) & (n) & $(\mathbf{\%})$ \\
\hline 1 & Tamat SD/MI & 23 & 29.9 \\
2 & Tamat SLTP/MTs & 14 & 18.2 \\
3 & Tamat SLTA/MA & 24 & 31.2 \\
4 & Diploma: DI, DII, DIII & 3 & 3.9 \\
5 & Sarjana: S1/S2 & 9 & 11.7 \\
6 & Sementara Kuliah & 4 & 5.2 \\
\hline & Total & $\mathbf{7 7}$ & $\mathbf{1 0 0 . 0}$ \\
\hline
\end{tabular}

Berdasarkan tabel di atas menunjukkan bahwa dominan pendidikan responden dari 77 responden adalah Tamat SLTA/MA yakni sebanyak 24 orang (31.2\%). Responden tamatan SD/MI sebanyak 23 orang (29.9\%), tamat SLTP/MTs sebanyak 14 orang (18.2\%), tamat Diploma: DI, DII, DIII sebanyak 3 orang (3.9\%), tamat Sarjana: S1/S2 sebanyak 9 orang (11.7\%), dan Sementara Kuliah sebanyak 4 orang (5.2\%).

4 Distribusi Responden Berdasarkan Umur

Tabel .4

Distribusi Responden Berdasarkan Umur Anak Di Wilayah Kerja Puskesmas Banggae I Kab. Majene

\begin{tabular}{cccc}
\hline NO & Umur Anak & (n) & $(\boldsymbol{\%})$ \\
\hline 1 & $2-2$ thn 11 bln & 25 & 32.5 \\
2 & $3-3$ thn 11 bln & 28 & 36.4 \\
3 & $4-5$ thn & 24 & 31.2 \\
\hline \multicolumn{7}{c}{ Total } & $\mathbf{7 7}$ & $\mathbf{1 0 0 . 0}$ \\
\hline
\end{tabular}


Vol. 16 No.2 Mei - Agustus 2021

Berdasarkan tabel di atas menunjukkan bahwa responden dengan persentase kelompok umur tertinggi yaitu umur 3-3 thn 11 bln yakni sebanyak 28 orang (36.4\%) dan persentase pada kelompok umur terendah yaitu 4-5 tahun yakni sebanyak 24 orang $(31.2 \%)$.

5. Distribusi Responden Berdasarkan Jenis Kelamin

Tabel 5

Distribusi Responden Berdasarkan Jenis Kelamin Anak Di Wilayah Kerja Puskesmas Banggae I Kab. Majene

\begin{tabular}{cccc}
\hline NO & Jenis Kelaminan Anak & $(\mathbf{n})$ & $(\boldsymbol{\%})$ \\
\hline 1 & Perempuan & 37 & 48.1 \\
2 & Laki-laki & 40 & 51.9 \\
\hline & Total & $\mathbf{7 7}$ & $\mathbf{1 0 0 . 0}$ \\
\hline
\end{tabular}

Berdasarkan tabel di atas dari 77 respoden, persentase perempuan sebanyak $37(48.1 \%)$ dan persentase laki-laki sebanyak $40(51.9 \%)$.

6. Distribusi Responden Berdasarkan Pemberian ASI-Eksklusif

Tabel .6

Distribusi Responden Berdasarkan Pemberian ASI-Eksklusif Di Wilayah Kerja Puskesmas Banggae I Kab. Majene

\begin{tabular}{cccc}
\hline NO & Pemberian ASI-Eksklusif & $(\mathbf{n})$ & $\mathbf{( \% )}$ \\
\hline 1 & Tidak ASI-Eksklusif & 19 & 24.7 \\
2 & ASI-Eksklusif & 58 & 75.3 \\
\hline & Total & $\mathbf{7 7}$ & $\mathbf{1 0 0 . 0}$ \\
\hline
\end{tabular}

Berdasarkan tabel di atas dari 77 responden, terdapat 58 orang (75.3\%) dalam kategori ASIEksklusif dan 19 orang (24.7\%) dalam kategori tidak ASI-Eksklusif.

7. Distribusi Responden Berdasarkan Berat Badan Lahir

Tabel .7

Distribusi Responden Berdasarkan Berat Badan Lahir Di Wilayah Kerja Puskesmas Banggae I Kab. Majene

\begin{tabular}{cccc}
\hline NO & Berat Badan Lahir & (n) & $(\boldsymbol{\%})$ \\
\hline 1 & $<2.500$ gram & 8 & 10.4 \\
2 & $\geq 2.500$ gram & 69 & 89.6 \\
\hline & Total & $\mathbf{7 7}$ & $\mathbf{1 0 0 . 0}$ \\
\hline
\end{tabular}

Berdasarkan tabel di atas, responden yang memiliki berat badan lahir $<2.500$ gram sebanyak 8 orang (10.4\%) sedangkan responden dengan berat badan lahir $\geq 2.500$ gram sebanyak 69 orang $(89.6 \%)$.

8. Distribusi Responden Berdasarkan Status Imunisasi 
Tabel .8

Distribusi Responden Berdasarkan Status Imunisasi Di Wilayah Kerja Puskesmas Banggae I Kab. Majene

\begin{tabular}{cccc}
\hline NO & Status Imunisasi & (n) & $(\boldsymbol{\%})$ \\
\hline 1 & Tidak Lengkap & 10 & 13.0 \\
2 & Lengkap & 67 & 87.0 \\
\hline & Total & $\mathbf{7 7}$ & $\mathbf{1 0 0 . 0}$
\end{tabular}

Berdasarkan tabel di atas, responden dengan status imunisasi lengkap sebanyak 67 orang $(87.0 \%)$ sedangkan responden dengan status imunisasi tidak lengkap sebanyak 10 orang $(13.0 \%)$

9. Distribusi Responden Berdasarkan Kejadian Stunting

Tabel .9

Distribusi Responden Berdasarkan Kejadian Stunting Di Wilayah Kerja Puskesmas Banggae I Kab. Majene

\begin{tabular}{cccc}
\hline NO & Stunting & (n) & $(\boldsymbol{\%})$ \\
\hline 1 & Stunting & 29 & 37.7 \\
2 & Normal & 48 & 62.3 \\
\hline & Total & $\mathbf{7 7}$ & $\mathbf{1 0 0 . 0}$ \\
\hline
\end{tabular}

Berdasarkan tabel di atas, responden yang mengalami stunting sebanyak 29 orang (37.7.\%) dan responden yang tidak mengalami stunting sebanyak 48 (62.3\%).

\section{Analisis Bivariat}

Dalam bagian ini akan dibahas mengenai analisa hubungan pemberian ASI-Eksklusif, berat badan lahir rendah, dan status imunisasi dengan kejadian stunting di wilayah kerja Puskesmas Banggae I Kab. Majene

1. Hubungan Pemberian ASI eksklusif dengan Kejadian Stunting

Tabel 10

Analisa Hubungan Pemberian ASI-Eksklusif Dengan Kejadian Stunting Di Wilayah Kerja Puskesmas Banggae I Kab. Majene

\begin{tabular}{cccccccc}
\hline $\begin{array}{c}\text { Pemberian ASI- } \\
\text { Eksklusif }\end{array}$ & \multicolumn{4}{c}{ Stunting } & Total & \% & $\begin{array}{c}\text { P } \\
\text { value }\end{array}$ \\
\hline $\begin{array}{c}\text { Tidak ASI- } \\
\text { Eksklusif }\end{array}$ & 8 & 10.4 & 11 & 14.3 & 19 & 24.7 & 0.645 \\
ASI-Eksklusif & 21 & 27.3 & 37 & 48.1 & 58 & 75.4 & \\
\hline Total & $\mathbf{2 9}$ & $\mathbf{3 7 . 7}$ & $\mathbf{4 8}$ & $\mathbf{6 2 . 4}$ & $\mathbf{7 7}$ & $\mathbf{1 0 0}$ & \\
\hline
\end{tabular}

\section{Chi-Square}

Pada tabel diatas menunjukkan bahwa proporsi balita yang tidak diberi ASI-Eksklusif memiliki status gizi stunting lebih sedikit yaitu sebanyak 8 orang (10.4\%) dibandingkan dengan balita yang diberi ASIEksklusif yaitu sebanyak 21 orang $(27.3 \%)$. Diperoleh nilai $\mathrm{p}=0.645(\mathrm{p}>0.05)$ dari hasil uji statistik, dengan 


\section{Vol. 16 No.2 Mei - Agustus 2021}

demikian dinyatakan bahwa tidak ada hubungan yang bermakna antara pemberian ASI-Eksklusif dengan kejadian stunting pada balita di wilayah kerja Puskesmas Banggae I.

2. Hubungan Berat Badan Lahir Rendah dengan Kejadian Stunting

Tabel .11

Analisa Hubungan Berat Badan Lahir Rendah Dengan Kejadian Stunting Di Wilayah Kerja Puskesmas Banggae I Kab. Majene

\begin{tabular}{cccccccc}
\hline \multirow{2}{*}{$\begin{array}{c}\text { Berat Badan } \\
\text { Lahir }\end{array}$} & \multicolumn{4}{c}{ Stunting } & Total & \% & $\begin{array}{c}\text { P } \\
\text { value }\end{array}$ \\
\cline { 2 - 6 } & Stunting & $\mathbf{\%}$ & Normal & $\boldsymbol{\%}$ & & & 0.466 \\
<2500 gram & 4 & 5.2 & 4 & 5.2 & 8 & 10.4 & 0.6 \\
$\geq 2500$ gram & 25 & 32.5 & 44 & 57.1 & 69 & 89.6 & \\
\hline Total & $\mathbf{2 9}$ & $\mathbf{3 7 . 7}$ & $\mathbf{4 8}$ & $\mathbf{6 2 . 3}$ & $\mathbf{7 7}$ & $\mathbf{1 0 0}$ & \\
\hline
\end{tabular}

Fisher's exact test

Pada tabel diatas menunjukkan bahwa proporsi balita dengan berat badan lahir <2500 gram memiliki status gizi stunting lebih sedikit yaitu sebanyak 4 orang (5.2\%) dibandingkan dengan balita dengan berat badan lahir $\geq 2500$ gram yaitu sebanyak 25 orang (32.5\%). Dari uji fisher's exact test diperoleh nilai p $=0.466(\mathrm{p}>0.05)$, dengan demikian dinyatakan bahwa tidak ada hubungan yang bermakna antara berat badan lahir rendah dengan kejadian stunting pada balita di wilayah kerja Puskesmas Banggae I.

3. Hubungan Status Imunisasi dengan Kejadian Stunting

Tabel .12

Analisa Hubungan Status Imunisasi Dengan Kejadian Stunting Di Wilayah Kerja Puskesmas Banggae I Kab. Majene

\begin{tabular}{cccccccc}
\hline Status Imunisasi & \multicolumn{4}{c}{ Stunting } & Total & \% & $\begin{array}{c}\text { P } \\
\text { value }\end{array}$ \\
\cline { 2 - 6 } & Stunting & $\mathbf{\%}$ & Normal & $\boldsymbol{\%}$ & & & 0.489 \\
Tidak Lengkap & 5 & 6.5 & 5 & 6.5 & 10 & 13 & 0.87 \\
Lengkap & 24 & 31.2 & 43 & 55.8 & 67 & 87 & \\
\hline Total & $\mathbf{2 9}$ & $\mathbf{3 7 . 7}$ & $\mathbf{4 8}$ & $\mathbf{6 2 . 3}$ & $\mathbf{7 7}$ & $\mathbf{1 0 0}$ & \\
\hline
\end{tabular}

Fisher's exact test

Pada tabel diatas menunjukkan bahwa proporsi balita dengan status imunisasi dasar tidak lengkap memiliki status gizi stunting lebih sedikit yaitu sebanyak 5 orang (6.5\%) dibandingkan pada balita dengan status imunisasi dasar lengkap yaitu sebanyak 24 orang (31.2\%). Dari uji fisher's exact test Diperoleh nilai $\mathrm{p}=0.489(\mathrm{p}>0.05)$, dengan demikian dinyatakan bahwa tidak ada hubungan yang bermakna antara status imunisasi dengan kejadian stunting pada balita di wilayah kerja Puskesmas Banggae I.

\section{Pembahasan}

Karakteristik Responden

Karakteristik Ibu

Pada penelitian ini, umur ibu responden dengan persentase tertinggi ada pada kelompok umur 30-39 tahun yakni sebanyak 36 orang $(46.8 \%)$ sedangkan persentase terendah ada pada kelompok umur 40-45 tahun yaitu sebanyak 7 orang $(9.1 \%)$. Dalam penelitian yang dilakukan oleh Fajrina 
(2016) ${ }^{(8)}$, kategori usia ibu dibagi menjadi usia beresiko dan tidak beresiko. Didalam penelitiannya didapatkan bahwa dari 82 responden, 69 ibu tidak dalam usia yang beresiko untuk hamil sementara terdapat 13 ibu termasuk dalam usia beresiko untuk hamil. Hal ini sesuai dengan teori yang dikemukakan (cunningham, 2006), usia reproduksi perempuan adalah 20-35 tahun. Pada usia $<20$ tahun, organ-organ reproduksi belum berfungsi sempurna dan $>35$ tahun terjadi penurunan reproduktif. Kehamilan dengan umur kehamilan 20-35 tahun merupakan masa aman karena kematangan organ reproduksi dan mental untuk menjalani kehamilan serta persalinan sudah siap.

Penelitian lain yang telah dilakukan oleh Agustiningrum (2016), kategori usia ibu juga dikategorikan menjadi 2 (dua) yaitu usia beresiko $(<25$ thn) dan tidak beresiko $(>25$ thn) dan didapatkan bahwa umur ibu yang berisiko (<25 tahun) sebanyak 13 orang $(46,4 \%)$ dan umur ibu yang tidak berisiko (>25 tahun) sebanyak 70 orang $(50,7 \%)$ pada kelompok kasus. Sedangkan pada kelompok kontrol terdapat sebanyak 15 orang $(53,6 \%)$ dan usia ibu yang tidak berisiko sebanyak 68 orang $\quad(49,3 \%) . \quad$ Dalam penelitiannyaAgustiningrum ${ }^{(30)}$ mengatakan bahwa usia ibu dianggap lebih berperan sebagai faktor psikologis ibu seperti penerimaan kehamilan anak sehingga berpengaruh terhadap pola pengasuhan anak, dalam hal ini pola asuh pemberian makanan.

Wanita umur dibawah 20 tahun masih berada dalam tahap pertumbuhan dan perkembangan sehingga kondisi hamil akan membuat dirinya harus berbagi dengan janin yang sedang dikandung untuk memenuhi kebutuhan gizinya. Sebaliknya ibu yang berumur lebih dari 35 tahun mulai menunjukan pengaruh proses penuaannya, seperti sering muncul penyakit berupa hipertensi dan diabetes melitus yang dapat menghambat masuknya makanan janin melalui plasenta ${ }^{(29)}$.

Pekerjaan ibu pada penelitian ini dengan persentase tertinggi yaitu tidak bekerja/URT yakni sebanyak 55 orang $(71.4 \%)$ dan persentase terendah yaitu dagang/wiraswasta yaitu sebanyak 4 orang (5.2\%). Ibu yang tidak bekerja mempunyai waktu yang cukup banyak untuk mengasuh anaknya terutama dalam pemberian ASI Eksklusif dan tidak akan mengganggu proses pemberian ASI Eksklusif. Pekerjaan mempengaruhi kesibukan \& status ekonomi. Orang yang bekerja biasanya mempunyai pola pikir yang lebih luas dibandingkan yang tidak bekerja sebab hal ini dipengaruhi oleh interaksi sosial yang lebih banyak dan lebih baik. Selain itu status pekerjaan ibu tergambar bahwa ibu yang berkerja yaitu perempuan yang berstatus sebagai ibu rumah tangga memiliki peran ganda dalam sebuah keluarga. Peran utamanya jika ketika memiliki aktivitas lain di luar rumah seperti bekerja, menuntut pendidikan atau pun aktivitas lain dalam kegiatan sosial akan berdampak terhadap pola asuh anak-anak mereka. Dengan peran ganda ini, seorang wanita dituntut untuk dapat menyeimbangkan perannya sebagai seorang ibu ataupun peran-peran lain yang harus 


\section{Vol. 16 No.2 Mei - Agustus 2021}

diembannya. Sebagai seorang ibu, ketika memiliki anak yang masih kecil, dirinya merupakan tempat bergantung bagi anakanaknya ${ }^{(28)}$.

Pada status pekerjaan ibu dalam penelitian Aridiyah, Rohmawati, \& Ririanty $(2015)^{(9)}$, bahwa anak balita stunting yang berada di wilayah desa terbanyak adalah tidak bekerja yaitu sebesar $71 \%$, sedangkan untuk di kota adalah bekerja dengan persentase sebesar 53,3\%. Penelitian lain yang dilakukan oleh Anshori (2013), menunjukkan bahwa ibu yang bekerja mempunyai anak pendek $(<-2 \mathrm{SD})$ lebih banyak di bandingkan dengan ibu yang tidak bekerja. Hal ini terjadi karena pada penelitian ini sebagian besar ibu tidak bekerja, sehingga ibu yang tidak bekerja akan mempunyai waktu yang lebih banyak dengan anaknya dan mempengaruhi peningkatan kualitas gizi anaknya.

Menurut Mubarak (2007) $)^{(31)}$, mengatakan bahwa lingkungan pekerjaan dapat menjadikan seseorang memperoleh pengalaman dan pengetahuan baik secara langsung maupun tidak langsung termasuk masalah gizi balita. Ibu yang mendapat pengetahuan tentang gizi balita tentu akan lebih berusaha untuk memberikan gizi yang baik kepada balita mereka.

Distribusi pendidikan responden pada penelitian ini dengan persentase tertinggi yaitu SLTA/MA sebanyak 24 orang (31.2\%) dan persentase terendah yaitu Diploma sebanyak 3 orang (3.9\%). Secara tidak langsung tingkat pendidikan ibu akan mempengaruhi kemampuan dan pengetahuan ibu mengenai perawatan kesehatan terutama dalam memahami pengetahuan mengenai gizi. Orang tua dengan tingkat pendidikan yang lebih tinggi berkesempatan untuk mendapatkan pekerjaan yang lebih baik, yang nantinya akan berdampak pada pendapatan dan ketersediaan pangan bagi keluarganya. Semakin tinggi tingkat pendidikan semakin mudah pula seseorang untuk menyerap informasi yang diperoleh, sehingga semakin besar peluang untuk memperoleh pengetahuan. Pengetahuan merupakan faktor yang sangat penting dalam membentuk perilaku seseorang ${ }^{(9)}$.

Pada penelitian yang dilakukan oleh Lastanto $(2015)^{(10)}$, sebagian besar responden masuk dalam pendidikan dasar yaitu lulus SD dan lulus SMP. Balita dengan gizi baik sebanyak 16 (53.3\%) orang dan balita dengan gizi kurang sebanyak 17 (56.7\%) orang. Meskipun ibu mempunyai pendidikan yang rendah tetapi dengan pengalaman yang lebih banyak menjadikan ibu mampu memberikan gizi seimbang kepada balitanya sehingga balita memiliki status gizi yang baik. Seseorang yang mempunyai pendidikan yang tinggi juga tidak selamanya akan di ikuti kondisi gizi yang baik bagi balita. Hal ini terjadi karena orang yang berpendidikan tinggi lebih banyak sibuk bekerja diluar rumah, maka memungkinkan tidak adanya waktu untuk memasak bagi kebutuhan bayi secara sehat. Meskipun hanya pendidikan rendah tetapi mempunyai kesempatan mengasuh bayi secara penuh, sehingga ibu 
dapat memberi asupan gizi yang baik bagi balitanya. Penelitian lain oleh Rahayu et al (2016) ${ }^{(11)}$ bahwa anak-anak yang dilahirkan dari ibu berpendidikan tinggi memiliki risiko yang lebih kecil daripada anak-anak yang dilahirkan dari ibu yang berpendidikan rendah. Hal tersebut dikarenakan ibu yang memiliki pendidikan tinggi akan lebih mudah menerima dan memproses informasi kesehatan.

Pendidikan seseorang yang meningkat akan mengajarkan individu mengambil keputusan yang terbaik untuk dirinya termasuk dalam memberikan asupan gizi kepada balita. Seseorang yang hanya tamat sekolah dasar akan berbeda tingkat pengetahuannya dibandingkan yang berpendidikan tinggi. Namun bukan berarti seseorang yang hanya tamat sekolah dasar kurang mampu menyusun makanan yang memenuhi persyaratan gizi. Hal ini dikarenakan jika orang tersebut rajin membaca informasi tentang gizi atau turut serta dalam penyuluhan gizi bukan mustahil pengetahuan gizinya akan lebih baik. ${ }^{(12)(13)}$

\section{Karakteristik Anak}

Pada penelitian ini distribusi responden berdasarkan umur dikelompokkan menjadi 3 (tiga) bagian. Persentase responden dengan umur $2-2$ tahun 11 bulan sebanyak 25 orang (32.5\%), kemudian persentase responden dengan umur 3 tahun 3 tahun 11 bulan sebanyak 28 orang (36.4\%), dan persentase responden dengan umur 4-5 tahun sebanyak 24 orang (31.2\%).
Penelitian yang dilakukan olehPutra $(2016)^{(14)}$, memperlihatkan bahwa umur anak terbanyak dalam menderita stunting adalah 12-24 bulan sebanyak 11 kasus $(35,48 \%)$. Hal ini dikarenakan bahwa usia 12-24 bulan adalah masa rawan dari balita yang identik sedang mengalami peralihan. Pada usia ini banyak perubahan yang terjadi, diantaranya perubahan pola makan dari semula ASI bergeser ke arah makanan padat, beberapa balita mulai mengalami kesulitan makan. Apabila pengasuhan tidak diperhatikan, maka balita lebih sering mendapatkan penyakit terutama penyakit infeksi. Kejadian penyakit infeksi yang berulang tidak hanya menurunkan berat badan atau akan tampak pada rendahnya nilai indikator berat badan menurut umur, akan tetapi juga indikator tinggi badan menurut umur.

Penelitian lain yang dilakukan oleh Wiyogowati (2012), ${ }^{(21)}$ bahwa kelompok umur 7-12 bulan memiliki risiko stunting 3,6 kali lebih besar dibandingkan dengan kelompok umur 37-59 bulan, sedangkan kelompok umur 13-36 memiliki risiko stunting 1,3 kali lebih besar dibandingkan dengan kelompok umur 37-59 bulan. Usia dua tahun pertama didalam kehidupan adalah usia yang paling kritis sehingga disebut “jendela peluang (window of opportunity)", karena mencegah kurang gizi sangat berarti untuk kelompok usia dua tahun pertama pada khususnya dan masyarakat pada umumnya. Meskipun kerusakan sudah terjadi dan seharusnya dihindari sejak dari usia 9 bulan sampai usia 24 bulan, kerentanan anak terhadap penyakit dan resiko kematian masih 


\section{Vol. 16 No.2 Mei - Agustus 2021}

tetap tinggi di usia lima tahun pertama. Itulah sebabnya banyak intervensi kesehatan dan gizi yang difokuskan pada anak bawah lima tahun

Distribusi responden berdasarkan jenis kelamin pada penelitian ini yaitu perempuan sebanyak 37 orang $(48.1 \%)$ dan laki-laki sebanyak 40 orang $(51.9 \%)$. Jenis kelamin menentukan pula besar kecilnya kebutuhan gizi bagi seseorang. Pria lebih banyak membutukan zat tenaga dan protein dibandingkan wanita. Pria lebih sanggup mengerjakan pekerjaan berat yang biasanya tidak biasa dilakukan oleh wanita. Tetapi dalam kebutuhan zat besi, wanita jelas membutuhkan lebih banyak dari pada pria (15).

Penelitian yang dilakukan oleh Dalimunthe $(2015)^{(16)}$, bahwa balita yang mengalami stunting lebih banyak perempuan dari pada laki-laki. Hasil yang sama pada penelitian yang dilakukan oleh Fitri $(2012)^{(15)}$, bahwa proporsi kejadian stunting pada balita lebih banyak ditemukan pada jenis kelamin perempuan dibandingkan balita dengan jenis kelamin laki-laki. Hal ini karena balita pada laki-laki lebih cenderung menjadi terhambat pertumbuhannya pada tahun pertama sedangkan perempuan lebih mungkin untuk menjadi terhambat pada tahun kedua kehidupan. Pada tahun pertama kehidupan laki-laki rentan mengalami malnutrisi daripada perempuan karena ukuran tubuh laki-laki yang besar dimana membutuhkan asupan energy yang lebih besar pula sehingga bila asupan makanan tidak terpenuhi dan kondisi tersebut terjadi dalam jangka waktu lama maka dapat menyebabkan gangguan pertumbuhan.

Hasil analisis regresi logistik menunjukkan, anak perempuan memiliki efek protektif atau risiko lebih rendah 29 persen terhadap stunting dibandingkan dengan anak laki-laki dengan nilai $\mathrm{OR}=0,71$ (0,53-0,96). Hal ini diduga karena faktor kecemasan atau kekhawatiran ibu serta kedekatan ibu terhadap anak perempuan. Anak perempuan dianggap anak yang lemah sehingga mendapatkan perhatiaan ekstra dibandingkan dengan anak laki-laki yang dianggap lebih kuat. Selain itu anak laki-laki cenderung memiliki aktivitas bermain yang lebih aktif dibandingkan dengan anak perempuan sehingga banyak energi yang keluar. Jika tidak diimbangi dengan asupan gizi dan makanan yang cukup dapat mencetus stunting.

\section{Hubungan Pemberian ASI-Eksklusif dengan Kejadian Stunting}

Hasil penelitian yang telah dilakukan oleh peneliti menunjukkan bahwa sebanyak 8 responden balita (10.4\%) mengalami stunting dengan riwayat ASI tidak eksklusif, namun terdapat 21 responden balita juga mengalami stunting walaupun mempunyai riwayat ASI eksklusif. Hasil penelitian menunjukan bahwa riwayat pemberian ASI eksklusif bukan faktor penyebab terjadinya stunting pada anak usia 2560 bulan. Didapatkan p-value $>0.05$, hal ini menunjukkan bahwa pemberian ASI Ekslusif tidak berhubungan secara signifikan terhadap 
kejadian stunting. Penelitian ini sejalan dengan penelitian yang dilakukan oleh Rahayuh et al (2016), bahwa tidak terdapat hubungan antara pemberian ASI eksklusif dengan kejadian stunting pada balita. Penelitian lain yang dilakukan di Kabupaten Tangerang juga menunjukkan hasil yang sama bahwa tidak ada hubungan yang signifikan antara ASI eksklusif dengan kejadian stunting ${ }^{(17)}$. Namun penelitian ini tidak sejalan dengan penelitian yang dilakukan di Kabupaten Gunung Kidul yang menunjukkan bahwa stunting mempunyai kaitan dengan pemberian ASI eksklusif pada balita ${ }^{(18)}$

ASI eksklusif tidak memiliki hubungan pada penelitian ini dimungkinkan karena ASI Ekslusif berpengaruh pada usia tertentu, yakni 0-6 bulan. Keluarga yang memberikan pola asuh baik terutama terhadap kebutuhan zat gizi, maka akan mempengaruhi status gizi anak. Pemberian MP-ASI yang tepat pada anak usia 12-24 bulan akan menurunkan risiko malnutrisi, karena pada usia tersebut kebutuhan zat gizi anak tidak dapat tercukupi hanya dari ASI saja. Perlu diperhatikan, pemberian ASI saja yang sudah terlalu lama atau lebih dari 6 bulan berkaitan dengan terjadinya kejadian pendek ${ }^{(19)}$.

ASI eksklusif adalah memberikan ASI kepada anak tanpa makanan dan minuman lain kepada bayi seperti air zam-zam, air gula, madu, dan sebagainya sejak lahir, kecuali obat dan vitamin. Menginjak usia 6 bulan, pemberian ASI saja tidak cukup memenuhi kebutuhan gizi bayi maka diperlukan sumber zat gizi tambahan dari makanan pendamping ASI. MP-ASI yang tepat dan baik merupakan makanan yang dapat memenuhi kebutuhan gizi sehingga bayi dan anak dapat tumbuh kembang secara optimal. MP-ASI diberikan secara bertahap sesuai dengan usia anak, disamping itu pemberian ASI terus dilanjutkan sebagai sumber zat gizi dan antibodi sampai anak mencapai usia 2 tahun atau lebih. Apabila tidak diberi MP-ASI dapat menyebabkan anak kehilangan kesempatan untuk melatih kemampuan menerima makanan lain yang menyebabkan growth faltering (gagal tumbuh) (20)

Asupan makanan berkaitan dengan kandungan nutrisi (zat gizi) yang terkandung didalam makanan yang dimakan. Dikenal dua jenis nutrisi yaitu makronutrisi dan mikronutrisi. Makronutrisi merupakan nutrisi yang menyediakan kalori atau energi, diperlukan untuk pertumbuhan, metabolisme, dan fungsi tubuh lainnya. Makronutrisi ini diperlukan tubuh dalam jumlah yang besar, terdiri dari karbohidrat, protein, dan lemak. Nutrisi (zat gizi) merupakan bagian yang penting dari kesehatan dan pertumbuhan. Nutrisi yang baik berhubungan dengan peningkatan kesehatan bayi, anak-anak, dan ibu, sistem kekebalan yang kuat, kehamilan dan kelahiran yang aman, resiko rendah terhadap penyakit tidak menular seperti diabetes dan penyakit jantung, dan umur yang lebih panjang. Tanpa nutrisi yang baik akan mempercepat terjadinya stunting selama usia 6-18 bulan, ketika seorang anak berada pada masa pertumbuhan yang cepat dan perkembangan otak hampir mencapai $90 \%$ dari ukuran otak ketika anak tersebut dewasa. Periode-periode ini merupakan periode dimana mulai 
Vol. 16 No.2 Mei - Agustus 2021

diperkenalkannya makanan pendamping ASI

(21).

\section{Hubungan Berat Badan Lahir Rendah dengan Kejadian Stunting}

Hasil penelitian yang telah dilakukan oleh peneliti menunjukkan bahwa sebanyak 4 responden balita $\quad(5.2 \%)$ mengalami stunting dengan riwayat berat badan lahir rendah, namun terdapat 51 responden balita juga mengalami stunting walaupun mempunyai riwayat berat badan lahir normal. Hasil penelitian menunjukan bahwa berat badan lahir rendah bukan faktor penyebab terjadinya stunting pada anak usia 25-60 bulan. Didapatkan p-value $>0.05$ (0.466), hal ini menunjukkan bahwa berat badan lahir rendah tidak berhubungan secara signifikan terhadap kejadian stunting.

Hal tersebut memang berlawanan dengan teori yang ada. Anak balita yang lahir dengan berat badan lahir rendah lebih berisiko untuk tumbuh stunting dibanding anak yang lahir dengan berat badan normal. Namun, BBLR tidak akan mempengaruhi pertumbuhan anak balita jika anak tersebut mendapatkan asupan yang memadai serta kondisi lingkungan mendukung pertumbuhan dan perkembangan anak balita (9). Walaupun balita lahir dengan berat badan rendah namun balita mendapatkan penanganan yang baik dari pihak Puskesmas, bukan tidak mungkin balita tersebut dapat mengejar pertumbuhannya.

Penelitian ini sejalan dengan penelitian yang dilakukan oleh Nasikhah
(2012) $)^{(22)}$, bahwa berat badan lahir tidak termasuk sebagai faktor terjadinya stunting. Hasil ini berbeda dengan penelitian Paramashanti, Hadi, \& Gunawan (2015) ${ }^{(23)}$, bahwa anak yang lahir dengan berat badan lahir rendah memiliki resiko mengalami stunting. Hal ini terjadi karena efek berat badan lahir terhadap stunting terbesar pada usia 6 bulan awal, kemudian menurun hingga usia 2 tahun. Bila pada 6 bulan awal, balita dapat melakukan kejar tumbuh maka ada kemungkinan balita dapat tumbuh dengan tinggi badan normal. Sedangkan subyek penelitian ini adalah balita usia 25-60 bulan sehingga berat badan lahir tidak memiliki pengaruh signifikan terhadap terjadinya stunting. Pertumbuhan setelah usia 6 bulan lebih dipengaruhi oleh pola asuh makan ibu yang baik dalam pemberian ASI eksklusif, MP-ASI, maupun perawatan kesehatan (22).

Berat bayi lahir rendah merupakan masalah kesehatan masyarakat yang banyak terjadi di Negara-negara miskin dan berkembang. Berat bayi lahir rendah erat kaitannya dengan mortalitas dan morbiditas janin dan bayi. Selain itu, bayi dengan BBLR dapat mengalami hambatan pertumbuhan dan perkembangan kognitif seiring dengan pertambahan usianya. Ukuran bayi ketika lahir berhubungan dengan pertumbuhan linear anak. Kelahiran bayi dengan berat badan lahir rendah (BBLR) menunjukkan adanya retardasi pertumbuhan dalam uterus baik akut maupun kronis dan akan memiliki kemungkinan mengalami gangguan 
pertumbuhan pada masa anak-anak karena lebih rentan terhadap penyakit infeksi (17)(22). Rendahnya pertambahan berat badan ibu saat hamil, penyalahgunaan obatobatan, distribusi zat gizi melalui plasenta tidak cukup, hipertensi kehamilan, anemia pada saat hamil, atau kondisi lainnya akan berkaitan dengan pertumbuhan pada janin dan prematur pada saat lahir. Berat lahir merupakan pengaruh yang kuat terhadap ukuran tubuh manusia di masa yang akan datang. Sebagian besar bayi dengan Intrauterine Growth Retardation (IUGR) tidak dapat mengejar masa pertumbuhannya untuk tumbuh secara normal seperti anakanak lainnya. ${ }^{(24)}$

Gizi janin bergantung sepenuhnya kepada ibu. Oleh karena itu kecukupan gizi ibu sangat mempengaruhi janin yang dikandungnya. Asupan energi dan protein yang tidak mencukupi pada ibu hamil dapat menyebabkan Kurang Energi Kronis (KEK). Wanita hamil berisiko mengalami KEK jika memiliki Lingkar Lengan Atas (LILA) $<23,5 \mathrm{~cm}$. Ibu hamil dengan KEK berisiko melahirkan bayi berat lahir rendah (BBLR) yang jika tidak segera ditangani dengan baik akan berisiko mengalami stunting) ${ }^{(1)}$

Berat bayi rendah yang diiringi dengan konsumsi makanan yang tidak adekuat, pelayanan kesehatan yang tidak layak, dan sering terjadi infeksi pada anak selama masa pertumbuhan juga dapat menyebabkan terhambatnya pertumbuhan dan menghasilkan anak yang stunting (Anisa, 2012).

\section{Hubungan Status Imunisasi Dengan Kejadian Stunting}

Hasil penelitian yang telah dilakukan oleh peneliti menunjukkan bahwa sebanyak 5 responden balita $(6.5 \%)$ mengalami stunting dengan riwayat status imunisasi tidak lengkap, namun terdapat 24 responden balita (31.2\%) juga mengalami stunting walaupun mempunyai status imunisasi yang lengkap. Hasil penelitian menunjukan status imunisasi bukan faktor penyebab terjadinya stunting pada anak usia 25-60 bulan. Didapatkan p-value >0.05 (0.489), hal ini menunjukkan bahwa status imunisasi tidak berhubungan secara signifikan terhadap kejadian stunting.

Penelitian ini sejalan dengan penelitian yang dilakukan oleh Chandra, puruhita, \& Susanto $(2011)^{(25)}$.menunjukkan bahwa status imunisasi tidak ada kaitannya dengan kejadian stunting. Penelitian lain yang dilakukan oleh Bentian, Mayulu \& Rattu (2015)(26), bahwa imunisasi tidak berhubungan dengan kejadian stunting pada balita. Penelitian ini berbeda dengan penelitian yang dilakukan oleh Hafid dan Nasrul (2016) ${ }^{(27)}$, bahwa kejadian stunting berhubungan dengan kelengkapan imunisasi. Penelitian lain yang dilakukan oleh Rahmad, Miko \& Hadi $(2010)^{(28)}$, juga mendapatkan hasil yang sama bahwa ada hubungan yang signifikan antara imunisasi dasar dengan status gizi balita dengan nilai $\mathrm{p}=0,014$.

Status Imunisasi bukanlah satusatunya faktor yang mempengaruhi kejadian stunting pada balita, namun banyak faktor yang mempengaruhi. Dalam hal ini 


\section{Vol. 16 No.2 Mei - Agustus 2021}

imunisasi yang lengkap belum tentu dapat menjamin anak terhindar dari suatu penyakit, dan tidak semua penyakit menular mempunyai vaksin atau imunisasi. Asupan yang tidak tercukupi juga dapat membuat balita beresiko mengalami stunting walaupun balita berstatus imunisasi yang lengkap.

Gizi kurang dan infeksi keduaduanya dapat bermula dari kemiskinan dan lingkungan yang tidak sehat serta sanitasi yang buruk. Selain itu juga diketahui bahwa infeksi yang menghambat reaksi imunologis yang normal dengan menghabiskan energi tubuh. Apabila balita tidak memiliki imunitas terhadap penyakit, maka balita akan lebih cepat kehilangan energi tubuh karena penyakit infeksi, sebagai reaksi pertama akibat adanya infeksi adalah menurunnya nafsu makan anak sehingga anak menolak makanan yang diberikan ibunya. Penolakan terhadap makanan berarti berkurangnya pemasukan zat gizi dalam tubuh anak.

Anak yang tidak diimunisasi secara lengkap akan terdapat gangguan kekebalan tubuh terhadap penyakit infeksi karena produksi antibodi menurun mengakibatkan mudahnya bibit penyakit masuk, hal dapat mengganggu produksi berbagai jenis enzim untuk pencernaan makanan. Makanan tidak dapat dicerna dengan baik dan ini berarti penyerapan zat gizi akan mengalami gangguan sehingga dapat memperburuk keadaan gizi. Sebagai reaksi pertama pada tubuh anak adalah berkurangnya nafsu makan sehingga anak menolak makanan yang diberikan ibunya, penolakan terhadap makanan berarti berkurangnya pemasukan zat gizi ke dalam tubuh anak. Dampak akhir dari permasalahan ini adalah gagalnya pertumbuhan optimal yang sesuai dengan laju pertambahan umur, sehingga akan mempertinggi prevalensi stunting ${ }^{(28)}$.

Berdasarkan hasil analisis dan penjelasan diatas, dari 3 (tiga) variabel yang diletiti oleh peneliti yakni pemberian ASI eksklusif, berat badan lahir rendah, dan status imunisasi, hasil analisis menunjukkan ke 3 (tiga) variabel tersebut tidak mempunyai hubungan dengan kejadian stunting. Stunting dipengaruhi oleh multifactor, oleh karena itu dapat disimpulkan bahwa kemungkinan terdapat faktor lain diluar variabel yang diteliti oleh peneliti yang dapat mempengaruhi kejadian stunting pada balita (25-60 bulan) di wilayah kerja Puskesmas Banggae I.

\section{Kesimpulan}

Pemberian ASI pada balita usia 25-60 bulan sebagian besar mendapatkan ASI eksklusif, Berat badan lahir balita usia 25-60 bulan sebagian besar memiliki berat badan normal, Status imunisasi balita usia 25-60 bulan sebagian besar berstatus imunisasi lengkap, Hasil analisis menunjukkan tidak terdapat hubungan antara pemberian ASI eksklusif, berat badan lahir rendah (BBLR), dan status imunisasi dengan kejadian stunting pada 
balita usia 25-60 bulan di wilayah kerja

Puskesmas Banggae I Kabupaten Majene.

\section{Saran}

Bagi Pelayanan Keperawatan

Puskesmas perlu mengadakan kegiatan penyuluhan bagi ibu anak balita terkait upaya untuk memenuhi status gizi dan meningkatkan status kesehatan Peningkatkan pelayanan kesehatan bagi puskesmas melalui kegiatan deteksi dini dengan mengukur tinggi badan anak balita secara rutin setiap bulan dengan menyediakan alat antropometri berupa microtoice disetiap posyandu. Dinas Kesehatan juga perlu melakukan pengumpulan data terkait angka kejadian stunting pada anak balita melalui survey penentuan status gizi (PSG) agar dapat diketahui didaerah mana yang paling dominan terjadinya stunting karena telah diketahui bahwa Sulawesi Barat masu dalam 3 (tiga) besar dengan prevalensı stunting tertinggi.

Dinas Kesehatan dan instansiinstansi lain yang terkait dapat memberikan solusi atau membuat kebijakan dalam rangka memperbaiki status gizi balita khususnya stunting, seperti mewajibkan setiap puskesmas untuk memantau setiap pertumbuhan dan perkembangan balita, tidak hanya berat badannya saja melainkan tinggi badannya juga dalam rangka memperbaiki status gizi balita khususnya stunting dan menerapkan Program Gerakan Nasional Sadar Gizi dalam Rangka 1000 Hari Pertama
Kelahiran untuk meningkatkan status gizi balita stunting.

Bagi Pendidikan Keperawatan

Hasil penelitian ini diharapkan dapat menjadi tambahan wawasan ilmu pengetahuan yang mencakup tentang gizi anak khususnya tentang pemberian ASI eksklusif, berat badan lahir rendah, dan status imunisasi.

Bagi Peneliti Selanjutnya

$\begin{array}{rlr} & \text { Diharapkan peneliti selanjutnya } \\ \text { dapat memperluas penelitian dengan }\end{array}$ menambah variabel lain yang memiliki pengaruh dengan kejadian stunting. Selain itu, diharapkan juga untuk penelitian selanjutnya dapat melanjutkan dengan metode penelitian dan analisis yang lain.

Bagi Responden

Responden penelitian dalam hal ini Ibu sebaiknya meningkatkan pengetahuan terkait status gizi pada anak, faktor yang mempengaruhi status gizi anak dan dampak yang dapat terjadi karena kekurangan gizi. Sehingga responden mampu melakukan tindakan pencegahan terhadap status gizi buruk anak khususnya kejadian stunting.

\section{DAFTAR PUSTAKA}

1. Kementerian Kesehatan RI. (2017). Data Pusat Informasi Profil Kesehatan Indonesia . Jakarta: Kementerian Kesehatan RI. 
Vol. 16 No.2 Mei - Agustus 2021

2. Oktarina, Z. (2012). Hubungan berat lahir dan faktor-faktor lainnya dengan kejadian stunting pada balita usia 24-59 bulan di provinsi aceh, sumatera utara,sumatera selatan, dan lampung tahun 2010 (Analisi Data Riskesdas 2010) (Skripsi). Depok: FKM-UI

3. Unicef Indonesia. (2010). Penuntun Hidup Sehat. Diunduh tgl 1 Juli dari http://www.depkes.go.id/resources/downloa d/promosi-kesehatan/buku-penuntun-hidupsehat.pdf

4. Mitra. (2015). Permasalahan Anak Pendek (Stunting) dan Intervensi untuk Mencegah Terjadinya Stunting (Suatu Kajian Kepustakaan). Jurnal Kesehatan KomunitaS. 2(6), 254-261.

5. Picauly, I., Toy, S.M. (2013). Analisis Determinan Dan Pengaruh Stunting Terhadap Prestasi Belajar Anak Sekolah Di Kupang Dan Sumba Timur, NTT. Jurnal Gizi dan Pangan. 8(1), 55-62.

6. Bentian, I., Mayulu, N., \& Rattu, A.J.M. (2015). Faktor Resiko Terjadinya Stunting Pada Anak TK Di Wilayah Kerja Puskesmas Siloam Tamako Kabupaten Kepulauan Sangihe Propinsi Sulawesi Utara. JIKMU. 5(1), 1-7.

7. Notoatmodjo, S. (2012). Metodologi Penelitian Kesehatan. Jakarta: PT Rineka Cipta

8. Fajrina, N. (2016). Hubungan Faktor Ibu Dengan Kejadian Stunting Pada Balita Di Puskesmas Piyungan Kabupaten Bantul (Naskah Publikasi). FIK-Universitas Aisyiyah Yogyakarta

9. Aridiyah, F.O., Rohmawati, N., \& Ririyanti, M. (2015). Faktor-faktor yang Mempengaruhi Kejadian Stunting pada Anak Balita di Wilayah Pedesaan dan Perkotaan. $e$ Jurnal Pustaka Kesehatan, 3 (1), 163-170.

10. Lastanto. (2015). Analisis Faktor Yang Mempengaruhi Kejadian Balita Gizi Kurang Diwilayah Kerja Puskesmas Cebongan (Skripsi). Surakarta: STIKes Kusuma Husada.

11. Rahayu, A. Yulidasari, F. Putri, A.O, Rahman, F. Rosadi, D. (2016). Faktor Risiko Yang Berhubungan Dengan Kejadian Pendek Pada Anak Usia 6-24 Bulan. Jurnal Kesehatan Masyarakat. 11 (2), 96-103.
12. Notoatmodjo. S. (2010). Promosi Kesehatan : Teori dan Aplikasi. Jakarta: PT Rineka Cipta

13. Nilekesuma, A. 2015). Hubungan Status Gizi Bayi Dengan Pemberian ASI Eksklusif, Tingkat Pendidikan Ibu, Dan Status Ekonomi Keluarga Diwilayah Kerja Puskesmas Padang Pasir. Artikel Penelitian Jurnal Kesehatan Andalas. 4 (1), 37-44.

14. Putra, O. (2016). Pengaruh Bblr Terhadap Kejadian Stunting Pada Anak Usia 12- 60 Bulan Di Wilayah Kerja Puskesmas Pauh Pada Tahun 2015 (Skripsi). FKMUniversitas Andalas.

15. Fitri. (2012). Berat Lahir Sebagai Faktor Dominan Terjadinya Stunting pada Balita (12-59 Bulan) di Sumatera (Analisis Data Riskesdas 2010) (Thesis). Depok: FKM-UI.

16. Dalimunthe, S.M. (2015). Gambaran FaktorFaktor Kejadian Stunting pada Balita Usia 24-59 Bulan di Provinsi Nusa Tenggara Barat (Analisis Data Sekunder Riskesdas 2010) (Skripsi). Jakarta: SKM Universitas Islam Negeri Syarif Hidayatullah.

17. Rahayu, L.S., Sofyaningsih, M. (2011). Pengaruh Bblr (Berat Badan Lahir Rendah) Dan Pemberian Asi Eksklusif Terhadap Perubahan Status Stunting Pada Balita Di Kota Dan Kabupaten Tangerang Provinsi Banten. Prosiding Seminar Nasional. 160169

18. Dewi, D.P. (2015). Status Stunting Kaitannya Dengan Pemberian Asi Eksklusif Pada Balita Di Kabupaten Gunung Kidul. Jurnal Medika Respati. 10(4), 60-65

19. Anugraheni, H.S., Kartasurya, M.I. (2012). Faktor risiko kejadian stunting pada anak usia 12-36 bulan di Kecamatan Pati, Kabupaten Pati. Eprints Undip.

20. Meilyasari, F. Isnawati, M. (2014). Faktor Risiko Kejadian Stunting Pada Balita Usia 12 Bulan Di Desa Purwokerto Kecamatan Patebon, Kabupaten Kendal. Journal of Nutrition College. 3(2), 16-25.

21. Wiyogowati, C. (2012). Kejadian Stunting pada Anak Berumur dibawah Lima Tahun (059 Bulan) di Provinsi Papua Barat Tahun 2010 (Analisi Data Riskesdas 2010) (Skripsi). Depok: FKM-UI. 
22. Nasikhah, R. (2012). Faktor Resiko Kejadian Stunting pada balita usia 24-36 bulan di Kecamatan Semarang Timur (Artikel Penelitian). Semarang: Universitas Diponegoro

23. Paramashanti, B.A. Hadi, H. Gunawan, I.M.A. (2015). Pemberian ASI eksklusif tidak berhubungan dengan stunting pada anak usia 6-23 bulan di Indonesia. Jurnal Gizi dan Dietetik Indonesia. 3(3), 162-174.

24. Hafid, F., Nasrul. (2016). Faktor Risiko Stunting pada Anak Usia 6-23 Bulan di Kabupaten Jeneponto. Indonesian Journal of Human Nutrition. 3(1), 42-53.

25. Candra, A. Puruhita, N. Susanto, JC. (2011). Risk Factors of Stunting among 1-2 Years Old Childrenin Semarang City. Media Medika Indonesia. 45(3), 206-212

26. Bentian, I., Mayulu, N., \& Rattu, A.J.M. (2015). Faktor Resiko Terjadinya Stunting Pada Anak TK Di Wilayah Kerja Puskesmas Siloam Tamako Kabupaten Kepulauan Sangihe Propinsi Sulawesi Utara. JIKMU. $5(1), 1-7$.

27. Hafid, F., Nasrul. (2016). Faktor Risiko Stunting pada Anak Usia 6-23 Bulan di Kabupaten Jeneponto. Indonesian Journal of Human Nutrition. 3(1), 42-53.

28. AL-Rahmad, A.H., Miko, A., \& Hadi, A. (2010). Kajian Stunting Pada Anak Balita Ditinjau Dari Pemberian Asi Eksklusif, MpAsi, Status Imunisasi Dan Karakteristik Keluarga Di Kota Banda Aceh. Jurusan Gizi Poltekkes Kemenkes RI Aceh, Jl. SoekarnoHatta, Lampeunerut, Aceh Besar

29. Yana., Musafaah., Yulidasari, F. (2016). Hubungan Antara Usia Ibu Pada Saat Hamil Dan Status Anemia Dengan Kejadian Berat Badan Lahir Rendah (Bblr). Jurnal Publikasi Kesehatan Masyarakat Indonesia. 3 (1). 20 25

30. Astuti D.K. (2016). Hubungan Karakteristik Ibu Dan Pola Asuh Gizi Dengan Kejadian Balita Stunted di Desa Hargorejo Kulonprogo DIY. Universitas Muhammadiyah Surakarta: Surakarta.

31. Mubarak. Wahid Iqbal. (2007). Promosi Kesehatan. Jogjakarta: Graha Ilmu. 